\title{
Replicating the Mechanical Print Aesthetic in Manuscripts before c.1500
}

Abstract: While Curt Bühler's well-known formulation sensibly posits that "every manuscript ascribed to the second half of the fifteenth century is potentially (and often without question) a copy of some incunable," little is known about how scribes copied print and what effects that practice had on the look of manuscripts. Given that the mechanical processes of the printing press caused print page design to change, this essay examines some of the ways in which scribes responded to that change and argues that scribes, tasked with creating bespoke copies of massproduced printed books, were quick to experiment with the new features of print. These were rapidly incorporated into their manuscripts meaning that the mechanical aesthetic of print soon became part of the scribes' repertoire.

The British Library copy of the Founders’ Book of Tewkesbury Abbey, MS Additional 36985, is designed to look like print. It is written in a neat italic hand that resembles the uniformity of type, its illustrations resemble the style of woodcuts, and its overall lack of colour reflects the monochrome aesthetic of undecorated printed books (fig. 1). But it is not, as Curt Bühler writes in his well-known formulation, “a copy of some incunable” (Fifteenth Century Book 16); rather, it is copied from an early sixteenth-century manuscript, Bodleian Library, MS Top. Glouc. d.2 (fig. 2). ${ }^{1}$ As Julian Luxford observes, the Founders’ Book was clearly “designed for a readership accustomed to the organization and appearance of printed books” (162). But what the book also demonstrates is that, by the late sixteenth century, scribes were able to replicate the print aesthetic even when they were copying from manuscripts. ${ }^{2}$ There are many other late-sixteenthcentury manuscripts like it, each of which resembles print so closely that it is difficult to distinguish them from printed books at first glance. ${ }^{3}$ As the introduction to this issue outlines, bibliographers have pointed to the co-existence and hybridity of manuscript and print long after the invention of the press, but we still know relatively little about how scribes adopted print features or how this practice became as common as the Founders’ Book suggests it was.

This essay explores some of the ways scribes responded to the new book aesthetic introduced by print in the first fifty or so years of the press. ${ }^{4}$ Starting with some of the changes 
that printing brought to the appearance of books, it examines how they were gradually adopted into manuscript practice, how they influenced the tastes of book collectors who commissioned bespoke manuscripts, as well as how scribes playfully experimented with print features in their productions. ${ }^{5}$ The examples under study are of English and continental manuscripts copied from printed books - some well-known, others less so - and the aim is to offer a more detailed picture of how a variety of scribes interacted with print. Scribes, especially those tasked with copying printed books for paying patrons, reproduced not only the text but also the visual aspects of print that were a by-product of its mechanical production. Their experiments meant that they introduced a mechanical aesthetic into manuscripts that brought together the appearance of massproduced print and the bespoke qualities of the manuscript.

\section{Print Innovations}

Early printed books of course looked like manuscripts simply because printers modelled their books on the only design available to them. ${ }^{6}$ To profit from their investment in presses, printers needed to produce the type of books they knew readers would expect and therefore purchase. ${ }^{7}$ Typefaces were cut to look like scribal hands - first formal book hands, then less-formal nearcursive hands (Gaskell, 17-26) - and later imitations of cursive hands also attempted to bring irregularity to the letter forms in order to imitate the natural discrepancies of writing (Gaskell, 26). Printers copied the presentation style that they found in manuscripts, leaving gaps for large initials, for instance, to be completed at a later stage of production in the way that scribes would have done. Printers soon realised, however, that the mechanical process of printing meant that they would need to include in their books features of page design that were not necessary in manuscripts. Books were not printed consecutively but out of sequence on unbound flat sheets that contained a number of pages on each side. These were folded and cut after printing to create gatherings, in contrast to the ready cut and folded quires used by scribes who copied the text 
sequentially folio by folio (Gaskell, 5). ${ }^{8}$ To aid in the setting of multiple pages, compositors therefore needed to include catchwords and quire signatures more regularly than manuscripts did. Therefore, catchwords were added to every page, changing the common manuscript practice of only adding them only to the final folio of a quire (Gaskell, 51; Farquhar, 39-40). These developments, at first fitfully adopted, gradually became a regular part of print production.

One large aesthetic change was the introduction of woodcuts in place of hand rendered illustrations. These were easy to incorporate into printed books because they could simply be printed at the same time as type (Gaskell, 154). Cutting into woodblocks inevitably changed the look of illustrations, most of which express detail in simple cross hatched shading which suited the process of carving (Gaskell, 155). While early printers experimented with printing in colour, producing images in colour in printed books was rare, meaning that most images in print were monochrome (Gaskell, 156). ${ }^{9}$ The expectation was that colour would be added by hand after printing should a purchaser wish to pay for it (McKitterick, 75; Parshall, xii) but woodcuts often remained single colour.

Further aspects of page design were changed by the compositor's process. Moveable type reduced the labour required to provide extra-textual apparatus: running titles, for instance, were printed in full on each folio because they could simply be taken, ready set, from pages that had already been printed (Gaskell, 51, 109); likewise, folio numbers would often occur with the full word "folio" or the abbreviation "fol." before them, again because it was easy for the compositor to leave the type in place once it was set. The spatial alignment enabled by standard-sized type and spacers allowed compositors to produce neat blocks of text that were aligned on both the left- and right-hand sides.

Each of these mechanical changes to the look of print can be seen in the late-sixteenth century Founders’ Book. The scribe carefully included running titles in capitals throughout the book, with "Registrvm” on the verso and "Theokvsbvriæ” on the recto. He provided folio 
numbers on every recto and supplied catchwords on every folio, both recto and verso, which would have been both time consuming and unnecessary in his copy. The text is written in an extremely neat italic hand with highly consistent lettering and spacing. ${ }^{10}$ The scribe also attempted to imitate the printer's even spacing but often had to split words, use line-fillers, or squeeze words into a line in order to replicate the print's straight right-hand edge. Finally, he changed the style of the illustrations he found in his exemplar to resemble the patterns and styles of woodcuts, rendered in black ink, most likely the same that was used to write the text, and shaded rather than painted to mimic the cross-hatching that is characteristic of woodcuts. ${ }^{11}$ The decorated initials throughout the book were also made to look like woodcuts and Luxford finds identical initials used in Christophe Plantin’s print shop in Antwerp in 1563 (176). These features are not found in the scribe's manuscript exemplar, suggesting that these elements of mass production had become firmly part of the scribe's repertoire by this time. But, while this example suggests a wholesale change in scribal practice a century after the invention of print, a more gradual or piecemeal adoption of print features can be traced in manuscripts produced earlier.

\section{Print Features in Manuscripts}

One of the best-known examples of a manuscript copied from a printed text is London, Lambeth Palace, MS 265, a large vellum copy of Caxton’s edition of Dictes or Sayings of the Philosophers ([1477], STC 6826), made c.1477 for presentation to Edward IV. ${ }^{12}$ The scribe repeatedly draws attention to the fact that the text is taken from Caxton's print by copying out a lengthy epilogue, added by Caxton, that describes the printer's relationship with Earl Rivers (fols 102r-106r) and a colophon stating that the book was “enprinted by me William Caxton” (fol. 102r). But despite these repeated nods to the printed exemplar, the manuscript in fact strives not to reproduce the print's aesthetic. M. R. James describes the decorative initials in the book as 
"modelled not very skilfully on the contemporary Italian work: the letter in fine burnished gold, the ground divided into fields of blue, pink, and green, dotted with white and filled with white branch-work" (414) which stand in stark contrast to the small gaps left for initials in the print edition. There is also an elaborate frontispiece that depicts the presentation of the manuscript by the author-translator, Earl Rivers, to the King, Queen, and their son for whom the book was intended (see fig. 2 in the introduction to this special issue). These additions are part of the bespoke, luxurious quality of the manuscript that caused Lotte Hellinga to argue that the manuscript “shows up Caxton’s printed book as a second-rate product” (77). The book may have been produced in tandem with the print (Hellinga, 77-80, 84-86) but the way in which the manuscript deliberately avoids replicating the features of print indicates the uncertainty of one scribe (or his commissioner) about the aesthetic worth of print. ${ }^{13}$

Standing in contrast to Lambeth Palace MS 265 is New York, Pierpont Morgan Library, MS M 801, a large manuscript copied c.1498 in Naples. ${ }^{14}$ The book brings together local-history chronicle material from a variety of print sources to which the scribe added his own work. It was likely produced for, as Bühler speculates, "presentation to a person of such eminence that a printed text was considered improper and unworthy for this purpose” ("The Facsciculus Temporum” 180). But while print may have been "unworthy” and the manuscript a more appropriate form for presentation, the style of the manuscript suggests that print was not rejected entirely. First, the scribe retained as much of the page design as he could from his printed exemplars. In combining multiple printed books, he juggled with different layouts. The first text in the manuscript, Ratdolt's edition of Fasciculus Temporum, was particularly tricky to copy as it features multiple text columns of different sizes interspersed with printed roundels. In appreciating that this would have been difficult for the compositor to set, the scribe has replicated as closely as he could the exact positioning of the text columns and roundels of his exemplar. The second text in the manuscript, Tuppo’s Cronaca di Partenope, has a simpler page 
design and the scribe switches to the single column of the Cronaca when copying it. He was not an accurate copyist and struggled to expand words and understand the printer's abbreviations, as Bühler points out (n.24). ${ }^{15}$ But his close attention to the careful and accurate replication of the aesthetic of his print exemplar indicates where his priorities lay.

Second, the scribe copied the many detailed illustrations depicting the local landscape, its architecture, historical events, and contemporary figures found in his printed exemplar. ${ }^{16}$ The woodcut copied into the manuscript on fol. 6v, for instance, depicts the city of Rome, including its walls and buildings (fig. 3). The scribe has copied the same perspective on the city as presented in the woodcut, with its entrance at the centre of the image, and has provided the same level of detail such as the brick of the walls and the tiles on the roofs (fig. 4). ${ }^{17}$ He was clearly interested in the landscape and architecture of the towns, which have been rendered so accurately that the curatorial description of a double page drawing on fols $116 \mathrm{v}-117 \mathrm{r}$ suggests that it "might well have been done by an engineer” (2). But the scribe was equally interested in the style of the woodcut he was copying. In the next image (fol. 7r), he copied the shape of the hills and buildings from the woodcut but also preserved the precise positions of the waves of the sea and the floating boats thereupon. Not only did he render the topography and architecture accurately, but he reproduced the overall look of the woodcut itself. ${ }^{18}$ When he provided decorative embellishments to the images in his exemplar, such as "supporting figures or 'putti'” ("The Facsciculus Temporum” 180), he did so in a way that emulates the style of the woodcuts, rendered with simple cross-hatched shading. He provided with a pen what the printer would have provided with a carved woodblock. Therefore, while a manuscript might have been more appropriate for presentation than a printed book, the scribe's incorporation of the look of print into his copy demonstrates the value he placed on the new mechanical aesthetic. He extended that aesthetic across the book and within his own text too. 
While this book suggests that the overall look of printed books was prized by scribes, they were also more gradually adopting specific print features into manuscripts, suggesting an interest in the small mechanical changes brought about by print. The scribe of Bodleian Library, MS Hatton 51, a copy of Caxton’s edition of the Confessio Amantis ([1483], STC 12142) produced c.1500, undertook the extra effort required to copy the repeated folio numbers, as well as the full word "folio", he found in his printed exemplar. ${ }^{19}$ Caxton himself was experimenting with folio numbers in his edition. He used Arabic numerals in the prologue and Roman numerals later in the volume and, in the first two gatherings, sometimes omitted folio numbers altogether. The scribe copied Caxton's use of first Arabic then Roman numerals and omitted them where they are omitted in the print exemplar. This was because the scribe understood Caxton's reason for including folio numbers in his volume: in addition to ensuring that the leaves were assembled in the correct order, they served to relate the contents of the folios to the table of contents provided at the start of the book. Tables of contents were rare in early print; and recognising the rarity of this feature, the scribe strove to replicate it and its related folio numbers exactly. But copying the table gave the scribe a number of problems, including the question of how to ensure that the folio numbered in the manuscript matched the contents of the same folios numbered in the print. This resulted in some unusual solutions, such as providing folio numbers on the versos as well as the rectos. Nonetheless, the scribe’s efforts to preserve this aspect of his print exemplar suggests the extent to which he valued the new and innovative features of print.

Newer additions to the printed book such as title pages were also imported into manuscripts from printed exemplars. Continental printers were using title pages as early as 1480 to showcase the contents of their books to potential purchasers, a feature that became increasingly important as the number of mass-produced printed books available to buyers grew. ${ }^{20}$ The scribe of Beinecke Library, $\mathrm{Zi}+2073$, was aware of the increased presence of title pages and undertook to copy one in his printed exemplar. Beinecke Library, $\mathrm{Zi}+2073$ is a 
compilation of four printed texts bound with a manuscript copy of Pro Marcello produced in Germany c.1500 from Conrad Kachelofen’s printed edition ([not after 1492]; ISTC ic00552350). ${ }^{21}$ The text was likely added to the compilation by hand because, as Cora E. Lutz suggests, "the compiler was unable to obtain a printed text” (263). These sorts of cheap additions to print by hand, possibly by the book's owner, were common practice. The title page of the manuscript was copied directly from the print exemplar, written in blackletter imitating type on an otherwise blank page. It replicates the aesthetic not only of the title page of the exemplar but also of those other printed texts with which it is bound, bringing the volume together into a single print-like aesthetic. The scribe’s sharp eye for printed detail is also noticeable in the way in which he attempted to integrate the varying styles of print bound in the volume with the style of the print exemplar he copied by hand. While the title pages replicate those found in his exemplar, the text in the manuscript replicates the look of the printed book that immediately precedes the manuscript in the volume. Copying the line length and spacing of this companion printed book, the scribe added a double imitation of print, matching his manuscript copy to both the style of its printed exemplar and the style of the printed texts it appends.

These examples together demonstrate the fragmentary adoption of print in the incunabula period and indicate the close attention these scribes paid to the aesthetic changes brought about by the printing press. Such manuscripts resist easy classification. Printing was, as Sandra Hindman describes it, a "hybrid trade” involving collaborations among a number of artisans such as "engravers, woodcutters, illuminators, printers, and scribes” (125). The terms "hybrid” or "hybridity" have typically been used to describe the crossover between manuscript and print in which manuscript and print are combined in a single binding, hand-produced elements are incorporated into already printed books, or where printed elements are incorporated into already finished manuscripts (e.g. Boffey, 76-80, Walsham and Crick, 12). The elaborate woodcuts created for books printed by Colard Mansion and William Caxton, for instance, were usually 
finished by hand, ${ }^{22}$ while plain manuscripts were cheaply and easily decorated by pasting or pinning woodcuts into them (McKitterick, 61). ${ }^{23}$ Both McKitterick and Hindman use the additional term "cross-fertilisation” to describe the execution of hand drawn miniatures and hand painting of woodcuts in printed books, and the pasting of woodcuts into manuscripts (McKitterick, 59; Hindman, 101). The term suggests that the pasting of machine produced elements into hand produced books and vice versa breeds something that is neither entirely printed nor entirely manuscript. ${ }^{24}$ Manuscripts that copy the patterns and styles of printed books extend this notion of cross-fertilization. They explore the value of making bespoke an aesthetic that is designed to be mass produced.

\section{Collectors’ Tastes}

Collectors of deluxe books had a hand in directing how manuscripts looked. A. S. G. Edwards and Carole Meale have shown that the introduction of print meant that the "possibility of ... [such] individuation was sharply curtailed” because print “emphasizes multiplicity, not particularity, and it is thus the exclusive nature of the relationship between producer and clientor patron-which is lost with the advent of printing” (96). What was available, however, was the individually decorated printed book. Printers themselves attempted to make bespoke copies of the printed books they produced which involved the hiring of scribes to execute decoration tailored to specific patrons. The French publisher Antoine Vérard, for instance, produced deluxe vellum copies of his printed books in which he had artists insert decorative borders with the arms of his patrons, erase his own printed device and add hand-painted versions, paint over woodcuts, erase chapter headings to be rewritten by hand, and add additional miniatures (Winn, 9).

Likewise, the publishers Johannes Heynlin and Guillaume Fichet made alterations to the printed books they presented to wealthy book collectors by adding illustrations and decorations that had been tailored to their patrons (Hindman, 132-133). But, despite such embellishments to 
individual copies, print was, nonetheless, mass produced. Collectors who wished for truly bespoke books and could afford to commission them instead had to look to scribes to satisfy their appetites and they often retained scribes for the purpose (Bühler Fifteenth-Century Book 28). The late fifteenth-century Florentine bookseller, Vespasiano da Bisticci, remarked that the Duke of Urbino would have been "ashamed” to have printed books appear alongside the manuscripts in his grand library (De la Mare, I, 87), reinforcing the notion that fifteenth-century book collectors valued the aesthetics of manuscripts over print. But Vespasiano’s statement has long been rejected as representing the views of other book collectors (e.g. by Eisenstein 48-49; Bühler Fifteenth-Century Book 62). As a counterargument, bibliographers have offered examples of Florentine book collectors who sent to Rome for printed books (Eisenstein, 49), King Matthias Corvinus of Hungary’s collection of both incunabula and manuscripts transcribed from them, ${ }^{25}$ and the Duke of Urbino’s library which itself had printed books put into the same luxurious bindings as manuscripts and was involved in establishing a press (Eisenstein 48).

Collectors also commissioned deluxe manuscripts that preserved the print aesthetic and such books challenge our notions of what was prized. Their books suggest that they saw print's features as desirable and sought a deliberately blended print-manuscript book form. One such collector was Abbot Raphael de Marcatellis, the natural son of the Duke of Burgundy (d. 1508). Marcatellis certainly had a taste for expensive books and a purse to match. He had a number of manuscripts copied from printed books for his library and, as Albert Derolez has remarked, of the 58 manuscripts now known to have belonged to him, only ten were "totally independent of print sources” (“Copying of Printed Books” 146). Marcatellis’s books were luxuriously made, often in large white vellum with specific patterns for borderwork, initials, and illustration that make them "distinguishable from the manuscripts made for other Flemish bibliophiles of the second half of the fifteenth century”(Derolez 1986, 146). ${ }^{26}$ His exacting standards suggest he had a taste for a very particular aesthetic. The luxurious quality of his manuscripts has led scholars 
(e.g., Walsham and Crick 12) to posit that they masked their sources in print, but in fact they often deliberately nod to the printed books from which they were copied. Beinecke Library, MS Mellon 25, a manuscript containing a compilation of astrological material copied c.1505, retains a direct reference to its printed exemplar. ${ }^{27}$ The scribe included the printer's greetings to his patron, “Erhardus Ratdolt Augustensis Impressor Alberto Rheni palatino superiorisque ac inferioris Bauarie duci potentissimo Illustrissimoque felicitatem”, as well as a longer prologue that praises the values of print (fol. 147v), indicating his source directly. Similarly, the scribe of another of Marcatellis’s books, Ghent, University Library, MS 112, a compilation of several printed texts, preserved the colophons in his exemplars. ${ }^{28}$ One states "impressum est hoc opus Venetiis duce virtute et comite fortuna” (fol. 85r) and another indicates that the next text was “impressarum parisii per Petrum Leuet” (fol. 135r). The scribe also included a long poem on the art of printing (fols. 87r). Derolez suggests that the scribe of this section of Ghent, University Library, MS 112 was “absent-minded” in reproducing these print features (The Library 160; “Copying of Printed Books” 149). ${ }^{29}$ However, scribes were accustomed to writing their own colophons or editing existing ones in their exemplar to remove references to previous scribes or printers. ${ }^{30}$ If, then, this precise replication of the printer's colophon, preface, and poem in praise of print is unlikely to be a slip, the deliberate reference to the printed exemplar demonstrates Marcatellis’s taste for making the printed book bespoke while retaining elements of print.

Other Marcatellis manuscripts preserve changes in print that were caused by the technical processes of printing, such as regular folio numbers and running titles. The scribe of Ghent, University Library, MS 7, an illustrated encyclopaedia copied in 1505 from Gregorius Reisch’s Margarita philosophica printed by Johann Schott in 1503 (USTC 675099) copies the printer's running titles. ${ }^{31}$ Whereas it was fairly common for fifteenth-century manuscripts to abbreviate running titles, often splitting them across a two-page spread, the ease of reusing ready-set running heads in print meant that they were usually repeated in full at the top of each folio. The 
print exemplar has, for instance, “Libri Primi Tractatus Primus” on the versos and "De Noticia Partium Orationis” on the rectos, describing the contents of each opening and the scribe copied these exactly on each recto and verso of his manuscript. In fact, he seems to have started with the intention of outdoing the print's running titles by writing out both halves of the running title, “Libri Primi Tractus Primus De Noticia Partium Orationis” on both the recto and versos of the first opening (fols $3 \mathrm{v}-4 \mathrm{r}$ ), but he soon realised that this was too labour intensive and reverted to imitating the print exactly. Doing so meant that the aesthetics of the printed page were replicated in the manuscript; but the scribe quickly identified that this aspect of the print exemplar also had a value beyond the aesthetic. The lengthy encyclopaedia would have been difficult to navigate without such running titles and the long index at the end of the volume would not have functioned properly without them. Copying these features as closely as he could meant that he retained the easy navigability of the printed text, making it a feature of his copy too.

Likewise, he recognised the efforts of the printer in including the glosses and images that are in the margins of the text. Printing in the margins was difficult (McKitterick, 38) and the printer of the encyclopaedia did so to ensure that the glosses and images enact their function in elucidating the text. In copying these into his manuscript, the scribe incorporates the features of print while exploring their value. For instance, where in the exemplar the printer has carefully provided the illustrative shapes that accompany the section on "Geometriae Practicae" in the margins (sig. k1r-sig. 18r), the scribe has copied those illustrations near-identically and replicated their marginal positioning (fols 121v-137r).

Such exploration of value can be better seen in the instances in which the scribes diverged from their print exemplars. For the most part, the scribe of Ghent, University Library, MS 7 copied his exemplar closely. There is striking resemblance, for instance, between the frontispiece in the manuscript and the woodcut from which it was copied (fol. 1v). Although it has been slightly repositioned to follow a table of contents and reduced in size to a half-page, the 
figures - of Philosophy with three heads, the seven figures representing the seven arts encircled in text that names each of them, and the four church fathers positioned above the circle and Aristotle and Seneca positioned below - are rendered exactly as they are in the woodcut. The manuscript illustrator clearly had the print in front of him when executing the image and, though he altered a few details of dress or expression, the image is almost identical.

But while many of the illustrations in the manuscript are copied closely from the printed book, the scribe or illustrator sometimes strays from the print exemplar. This suggests that, while he adopted some features of print, he also questioned their function. Derolez lists a few images which have small deviations from the exemplar, such as "the map of the Sky which has been distributed over two pictures (fols 218r and 139r)" (The Library 208). Some of these are obvious additions in creating a bespoke book, such as on fol. $197 \mathrm{v}$, where the half-page that is left blank following the end of a chapter is taken up with a monogram rendered on a bright blue ground with a swan and Marcatellis's device, which replace the woodcut in the print (sig. A7v). There is also a series of monograms from fol. 300v that of course are not in the print exemplar. But equally, there are other changes to the print exemplar that are not directly required in tailoring the book to its commissioner. Most strikingly, a woodcut of Eve being created from Adam's rib that prefaces Book Nine, which is repeated twice in the edition (sig. x6v and sig. D1v), is replaced with an entirely new image of Adam and Eve’s temptation and expulsion from Eden (fol. 216r). It would have been relatively easy for a printer to repeat the woodcut but much more difficult for the scribe or illustrator to copy it twice. But changing the image altogether to one perhaps more fitting to preface a section on “origine rerum naturalium” (which starts just below it, fol. 216r) instead shows the scribe’s careful attention to the text he was copying, not only adding Marcatellis's monogram to the manuscript to make it bespoke but also editing perceived errors in his printed exemplar. Most of the chapters in the exemplar have woodcuts that attempt to illustrate the subject matter to come, such as that of "Nicostrata", inventor of the alphabet, 
printed ahead of the chapter on grammar; the scribe provided a similarly fitting image for the “origine rerum naturalium” chapter.

Such instances in which he alters his print exemplar suggest that he found it necessary to combine print features with styles more often found in manuscripts. Smaller changes made to the print, such as providing a background of blue sky to the image of the "salamandra" on fol. 219r where the creature in the print has none (sig. D4r), bring together the aesthetics of woodcuts, rendered in simple cross-hatched style, with more elaborate painted miniatures more commonly found in expensively-produced manuscripts. These sorts of changes are also made in MS Mellon 25, the compilation of astrological material previously described. The scribe copied the series of woodcuts "illustrating the horoscopes of individuals born at certain dates and places ... [and] the temperamental qualities of each individual” directly from Ratdolt’s print edition (Witten and Pachella, 170; see fols 191r-238v). He rendered these in close imitation of the woodcuts, emulating the simple line drawings and cross hatched shading that characterise carved woodblocks. But he also sought to refine these illustrations by rendering them in full colour (figs. 5 and 6). Printing in more than one colour was certainly more difficult than using multiple inks in manuscripts. Because of the expectation that printed woodcuts would be coloured by hand, the first experiments in printing in colour attempted to emulate the look of woodcuts that had been hand painted (Parshall, xii). In Ghent, University Library MS 7 and MS Mellon 25, the scribes went to the double effort of first imitating the woodcuts as closely as possible by hand and then painting over them. These scribes brought the manuscript back full circle: they have produced hand-drawn and coloured images that are modelled on hand-coloured woodcuts that were themselves modelled on hand-drawn images. The result is a blended manuscript-print aesthetic, one which attempts to replicate the look of mass produced images while simultaneously and paradoxically making the mass produced image bespoke. 
Another well-known book collector, Roger Thorney (d. 1515), owned Oxford, St John’s College, MS 266, a manuscript copy of Lydgate's Siege of Thebes produced in the last quarter of the fifteenth century. ${ }^{32}$ Although not copied from a print exemplar but from another manuscript, the manuscript was designed to append a compilation of three printed texts. ${ }^{33}$ It is likely that Thorney had the manuscript made to supplement his printed texts. The look of the entire book is bespoke, but it is made in such a way that combines the aesthetics of both manuscript and print to a greater extent than Marcatellis’s books do. The scribe painted the woodcuts of the printed portion of the book and provided decorated coloured initials. He also copied out running titles unabbreviated on most folios of his copy, imitating the running titles in the print with which the manuscript is bound. He ruled the book in red ink, not only the manuscript portion where the ruling is a functional guide for the scribe, but also the printed portion where the ruling has only a decorative and not a practical function. The efforts to bring the book together and to combine the aesthetic of print and manuscript production, likely at the behest of Thorney, suggests the appeal of such a blended aesthetic. ${ }^{34}$ The book which combines both the mass produced look of print with the careful artistry of scribal production.

\section{Scribal Experiments}

Scribes were often required to copy printed books in specific circumstances which affected how far they were able to adapt its features. For instance, they were commonly employed to fill lacunae in print, sometimes in the printing house itself. When pages ran short in a copy of Wynkyn de Worde’s Horae beatissime virginis Marie (1510, STC 15908.5, now British Library, C.123.d.32), for example, the print shop hired a scribe to supply these by hand (sig. D3-sig.D6) (McKitterick, 108). The scribe carefully matched the look of the print he appended, cutting his quill in order to ensure that his script size imitated the size of the type he copied, which in turn ensured an almost straight right-hand edge that matched the set block of type. He styled his hand 
on the type used in the print and finished the supplementary pages with red and black flourishes that imitate those in the print, providing nearly identical running titles, folio numbers, and a quire signature. He then stamped woodcuts into gaps that he had carefully provided so that the manuscript addition became seamlessly part of the print it appended. Given that he had been employed specifically to fill such a gap, the scribe of course aimed to reproduce the look of print as closely as he could; but the expertise with which he executed the imitation indicates the extent to which such imitation was becoming increasingly part of scribes’ skillset.

When scribes were not specifically tasked with supplementing print, their work shows that they were experimenting with print features in their manuscripts, thereby expanding their repertoire. As part of this experimentation, scribes began to import print's mechanical features into their manuscripts not from their print exemplars but from other printed books. In MS Mellon 25, for instance, the scribe has combined two printed exemplars: the series of astrological texts printed by Bonetus Locatellus and Engles’s Astrolabium printed by Erhard Ratdolt. ${ }^{35}$ Whereas Locatellus’s edition has folio numbers, Ratdolt's volume does not. Aware of the common inclusion of folio numbers in print, the scribe extended these throughout his manuscript so that all of the texts in the book are provided with numbers in red ink prefixed by "fo" or "fol". His manuscript therefore follows a practice common in printed books generally, if not the execution found in those exemplars he copied specifically.

Likewise, the scribe of Manchester Chetham’s Library, MS Mun.A.4.104 (previously MS 6709) both adopted and adapted print features more freely, attempting to develop their use. ${ }^{36}$ The manuscript, copied in March 1490, contains extracts of Lydgate’s Life of Our Lady copied from Caxton ([1483], STC 17023/4) and the Second Nun's Tale and Prioress's Tale copied from Caxton's second edition of The Canterbury Tales ([1483], STC 5083). ${ }^{37}$ Although none of the three print exemplars have folio numbers, the scribe provided them throughout his manuscript. He then provided quire signatures throughout his manuscript but in an unusual way. From the 
second quire onward, he wrote the quire number and folio number in full so that they read, for instance, “Quaterno $1^{\circ}$ folio $1^{\circ}$. "38 He positioned them centrally above the text, taking up the space usually occupied by a running title. The scribe provided far more quire signatures than were typically used in print, which customarily had quire signatures on only the first four leaves of each gathering. The quire and folio numbering relate to a table of contents the scribe provides at the start of his manuscript. He therefore repurposed the system used by printers to organise the production of their books into his own private and unique method of organisation.

These scribes preserved aspects of the print aesthetic while experimenting with its use in manuscripts, an experiment they would not have undertaken had the mechanical processes of print production left page design unchanged. These sorts of playful experiments in the late fifteenth and early sixteenth centuries that paved the way for the more comprehensive adoption of print features in manuscripts produced in the mid- to late sixteenth century, such as the Founders’ Book with which this essay began. ${ }^{39}$ Manuscripts copied from printed books were popular and the practice widespread; but looking more closely at the ways in which some of the earlier manuscripts were produced demonstrates how scribes were absorbing mechanical features of print into their own productions, willingly responding to a change in book forms and in readerly tastes. In the series of lectures that became The Fifteenth-Century Book, Bühler's central argument is that "there is very little real difference between the fifteenth-century manuscript and the incunabula” (16). This is certainly true of the examples described here, but not only because it was sometimes more practical to copy from a printed exemplar than a manuscript. Scribes also made conscious choices to adopt the aesthetic changes brought about by the printing press and to integrate them with their own practices. The practical changes required by the press were gradually divorced from the material form in which they originated, resulting in a type of book that moves beyond "hybridity" to offer blended manuscript-print aesthetic.

\section{Manuscripts}


Ghent, University Library, MS 7

Ghent, University Library, MS 112

London, British Library, C.123.d.32

London, British Library, MS Additional 29506

London, British Library, MS Additional 36985

London, Lambeth Palace, MS 265

Manchester, Chetham's Library, MS Mun.A.4.104 (previously MS 6709)

New Haven, Yale University, Beinecke Library, MS Mellon 25

New Haven, Yale University, Beinecke Library, Zi +2073

New York, Pierpont Morgan Library, MS M 801

Oxford, Bodleian Library, MS Douce 261

Oxford, Bodleian Library, MS Hatton 51

Oxford, St John's College, MS 266

\section{Works Cited}

Blake, N. F. "Manuscript to Print”. Book Production and Publishing in Britain 1375-1475.

Edited by Jeremy Griffiths, Derek Pearsall. Cambridge University Press, 1989. 403-432.

Boffey, Julia. Manuscript and Print in London c. 1475-1530. British Library, 2012.

Bone, Gavin. "Extant Manuscripts Printed from by W. De Worde with Notes on the Owner, Roger Thorney.” The Library 12 (1932): 284-306.

Bühler, Curt F. “The Fasciculus Temporum and Morgan Manuscript 801.” Speculum 27 (1952): 178-183.

---. “The Thirteenth Recorded Manuscript of the Cronaca di Partenope.” PMLA 67 (1952): 580584.

---. The Fifteenth-Century Book: the Scribes, the Printers, the Decorators. University of Pennsylvania Press, 1960.

De la Mare, Albinia C. Vespasiano da Bisticci: Historian and Bookseller. 1966. University of London. PhD Dissertation. EThOS, https://ethos.bl.uk/OrderDetails.do?uin=uk.bl.ethos.298698.

Derolez, Albert. The Library of Raphael de Marcatellis, Abbot of St Bavon's, Ghent, 1437-1508. E. Story-Scientia Ltd, 1979.

---. "The Copying of Printed Books for Humanistic Bibliophiles in the Fifteenth Century." From Script to Book: A Symposium. Edited by Hans Bekker-Nielsen, Marianne Bærch, Bengt Algot Særensen. Odense University Press, 1986. 140-160.

---. "Nieuwe gegevens in verband met de ateliers van Raphaël de Mercatellis.” Miscellanea Neerlandica I: Opstellen voor Dr. Jan Deschamps ter gelegenheid van zijn zeventigste verjaardag: bibliografie, handschriftenkunde, miniatuurkunst. Edited by Elly CockxIndestege, Frans Hendrickx. Peeters, 1987. 479-503.

Edwards, A. S. G. "Decorated Caxtons.” Incunabula: Studies in Fifteenth-Century Books Presented to Lotte Hellinga. Edited by Martin Davies. British Library, 1999. 493-506. Print.

Edwards A. S. G. and Carol M. Meale, “The Marketing of Printed Books in Late Medieval England.” The Library 15 (1993): 95-124. 
Eisenstein, Elizabeth. The Printing Press as an Agent of Change: Communications and Cultural Transformations in Early-Modern Europe (Complete in One Volume). Cambridge University Press, 1979.

Erler, Mary C. "Pasted-In Embellishments in English Manuscripts and Printed Books c.14801533.” The Library 14 (1992): 185-206.

Farquhar, James Douglas. "The Manuscript as a Book”. Pen to press: illustrated manuscripts and printed books in the first century of printing. Hindman and James Douglas Farquhar. University of Maryland, 1977. 11-99.

Gaskell, Philip. A New Introduction to Bibliography. Oak Knoll Press, 1972.

Gutierrez, Nancy and Mary C. Erler, "Print into Manuscript: A Flodden Field News Pamphlet (British Library Ms Additional 29506).” Studies in Medieval and Renaissance History 8 (1986): 187-230.

Hellinga, Lotte. Caxton in Focus: the Beginning of Print in England. The British Library, 1982. Hindman, Sandra. "Cross-Fertilization: Experiments in Mixing the Media”. Pen to press: illustrated manuscripts and printed books in the first century of printing. Hindman and James Douglas Farquhar. University of Maryland, 1977. 101-156.

James, M. R. Claude Jenkins. Descriptive Catalogue of the Manuscripts in the Library of Lambeth Palace Part I. Cambridge University Press, 1930.

Kelly, Samantha. The Cronaca di Partenope: An Introduction to and Critical Edition of the First Vernacular History of Naples, c. 1350. Brill, 2011.

Lutz, Cora E. “Manuscripts Copied from Printed Books.” Yale University Library Gazette 49 (1975): 261-267.

Luxford, Julian. “'Secundum originale examinatum': The Refashioning of a Benedictine Historical Manuscript.” Design and Distribution of Late Medieval Manuscripts in England. Edited by Margaret Connolly, Linne R. Mooney. York Medieval Press, 2008. 161-179.

McKitterick, David. Print, Manuscript and the Search for Order 1450-1830. Cambridge University Press, 2003.

Morison, Stanley. “The Development of Hand-Writing: An Outline.” The English writingmasters and their copy-books: 1570-1800. Ambrose Heal. Cambridge University Press, 1931. xxiii-xl.

Osley, A. S. Scribes and Sources: Handbook of the Chancery Hand in the Sixteenth Century. Faber, 1979.

Parshall, Peter. "Preface: The Problem of Printing in Colour.” Printing Colour 1400-1700: History, Techniques, Functions and Receptions, edited by Ad Stijnman and Elizabeth Savage. Brill, 2015, pp. xii-xvi.

Ross, D. J. A. "Methods of Book Production in a Fourteenth Century French Miscellany (BM Royal 19. D. 1).” Scriptorium 6 (1952): 63-75.

Schuppisser, Fritz Oskar. “Copper Engravings of the 'Mass Production' Illustrating Netherlandish Prayer Manuscripts.” Masters and Miniatures. Proceedings of the Congress on Medieval Manuscript Illumination in the Northern Netherlands (Utrecht, 10-13 December 1989). Edited by Koert van der Horst, Johann-Christian Klamt.

Davaco, 1991. 389-400. 
Seymour, M. C. “MSS Douce 261 and Egerton 3132A and Edward Banyster.” Bodleian Library Record 10 (1980): 162-165.

Savage, Elizabeth. “A Printer's Art: The Development and Influence of Colour Printmaking in the German Lands, c.1476-c.1600.” Printing Colour 1400-1700: History, Techniques, Functions and Receptions, edited by Ad Stijnman and Elizabeth Savage. Brill, 2015, pp. 93-102.

Smith, Margaret. The Title-Page: Its Early Development, 1460-1510. British Library, 2000. Walsham, Alexandra and Julia Crick. "Introduction: Script, Print, and History.” The Uses of Script and Print, 1300-1700, edited by Alexandra Walsham and Julia Crick. Cambridge University Press, 2004, pp.1-20.

Winn, Mary Beth. Anthoine Vérard, Parisian Publisher, 1485-1512: Prologues, Poems, and Presentations. Droz, 1997.

Witten, L. C., R. Pachella. Alchemy and the Occult: a Catalogue of Books and Manuscripts from the Collection of Paul and Mary Mellon Given to Yale University Library, III: Manuscripts 1225-1671. Yale University Library, 1977.

Woudhuysen, H. R. Sir Philip Sidney and the Circulation of Manuscripts 1558-1640. Clarendon Press, 1996.

\footnotetext{
Notes

${ }^{1}$ Selected images of the exemplar are available via Digital Bodleian: https://digital.bodleian.ox.ac.uk. Some images are reproduced in Luxford.

${ }^{2}$ Luxford suggests that MS Additional 36985 was "probably made during the late sixteenth century" or "a date in the early seventeenth century" (162 and 176 respectively).

${ }^{3}$ For example, British Library, MS Additional 29506 and Oxford, Bodleian Library MS Douce 261.

Both are written in a hand which attempts to imitate type and Additional 29506 uses different scripts to imitate the different types the scribe must have found in his exemplar (a tract which is now lost); they also both have illustrations which imitate the patterns and styles of woodcuts. Gutierrez and Erler date MS Additional 29506 to the end of the sixteenth century (190). MS Douce 261 has the date "1564" written at the end of the book (fol. 48v); see also Seymour 162-165 and Woudhuysen 244. Selected images of MS Douce 261 are available via Digital Bodleian: https://digital.bodleian.ox.ac.uk. ${ }^{4}$ As befits a volume on "Visualizing Print in Manuscript", this article focusses on visual crossovers between the two book forms, though of course these visual features interacted with textual changes in the manuscript brought about by print. I consider these elsewhere.

${ }^{5}$ This essay focusses on scribes that produced books and not those that copied for "the courts... the chanceries, the archives, and in the other offices of government and ... of commerce.” As Bühler points out, "this group was left quite undisturbed by the advent of the new invention." (FifteenthCentury Book, 24).

${ }^{6}$ David McKitterick addresses the "historical fallacy" of describing printed books as removing printspecific features such as title pages and colophons in order to imitate manuscripts (35-37).

${ }^{7}$ As McKitterick puts it, "most [readers], we may be sure, viewed the printed book and the manuscript book in much the same way" (37).

${ }^{8}$ See also N. F. Blake, 408. Of course, scribes sometimes also copied on flat sheets: see, for instance D. J. A. Ross.

${ }^{9}$ On early experiments with printing colour in Germany, which was much more common, see Savage 93-102.

${ }^{10}$ The lettering imitated here is influenced by simultaneous developments in both type and script. While type was created to standard sizes in the early to mid-sixteenth century (Gaskell 13), which enabled greater consistency in text layout, of course type was modelled on clear scripts such as developing italic hands. Early sixteenth century writing masters encouraged a "geometry" of script,
} 
that is a consistent ratio of height to width of individual letter forms, and such regularised letter forms encouraged further development of type. On this see: Gaskell, 12-33; Osley, 19; Morison, xxiii-xl.

${ }^{11}$ While attempting to copy their detail and overall composition, the scribe makes a few mistakes. As Luxford describes: "In a few cases, the maker of the later manuscript was unable to comprehend the symbolic object represented in the hands of this or that lord, and depicted it wrongly" (173).

${ }^{12}$ It is described as “a verbatim copy of Caxton’s printed edition” (James and Jenkins, 412).

${ }^{13}$ British Library, Harley MS 4425, made for Engelbert II, Count of Nassau and Vianden, is another such book, copied from a printed text without replicating the features of print. The images are decidedly not those of the print exemplar.

${ }^{14}$ As dated in the "Curatorial Description". The book combines Fasciculus Temporum copied from Ratdolt's print edition (1481; ISTC ir00264000) with Cronaca di Partenope copied from the edition produced by Francesco Del Tuppo ([1486-90]; ISTC iv00273600), and further chronicle material print (Bagni di Pozzuoli) with a unique autograph text (Ferraiolo, Cronaca della Napoli argonese, known as the Ferraiolo Cronaca). On the printed exemplar of Fasciculus Temporum, see Bühler, "The Fasciculus Temporum” (1952a); on the printed exemplar of Cronaca, see Bühler, “The Thirteenth Recorded Manuscript” (1952b). On the Ferraiolo Cronaca, see Kelly, 122.

${ }^{15}$ Bühler also describes how the scribe copied paragraph divisions exactly as he found them in the print although the layout made little sense in his manuscript copy. See Bühler 1952a, 180 and 1952b, 583.

${ }^{16}$ Indeed, Bühler used the woodcuts to help identify the exemplar, 1952a, 179.

${ }^{17}$ A few of the buildings are eliminated.

${ }^{18}$ The scribe was clearly not an accomplished artist as his copy of the woodcut of Christ on fol. 20r is a poor attempt at imitating the woodcut. While he has tried to copy the arrangement of the figure's face and hands, including the positioning of the eyes and mouth, the twist of the scroll behind the figure, and the foliage around his feet, he manages to do so only crudely.

${ }^{19}$ For a full discussion of this manuscript, see Nafde, "Gower from Print to Manuscript: Copying Caxton in Oxford, Bodleian Library, MS Hatton 51”. John Gower in Manuscripts and Early Printed Books. Edited by Martha Driver, Derek Pearsall and R. F. Yeager. Boydell \& Brewer, 2020. pp. 189200.

${ }^{20}$ For a discussion of the origins and development of the title page, see Smith.

${ }^{21}$ The four printed texts are De consolatione philosophiae (1486; ISTC ib00781000) and De proprietatibus rerum (1492; ISTC ib00141000) both printed by Anton Koberger, Liber

Ethymologiarum Isidori Hyspalensis Episcopi, printed by Michael Furter (1489; ISTC ii00185000), and Oratio Philippica printed by Martin Landsberg ([1495]; ISTC ic00553000).

${ }^{22}$ See, for instance, Edwards on the decoration of Caxton's books.

${ }^{23}$ Printers were savvy about the potential for woodcuts to be used in this way and quickly realised the benefits of mass producing images specifically for such pasting into both manuscripts and printed books. This meant such images were easily available. McKitterick gives a number of examples of woodcuts that were pasted into manuscripts, printed books, or elsewhere (57-66). See also Hindman, 104-108; Erler, 185-206.

${ }^{24}$ Both McKitterick and Hindman discuss manuscripts that copy print only briefly: McKitterick, 5859; Hindman, 102-103.

${ }^{25}$ Bühler provides examples of a number of wealthy book collectors in Italy, Germany, France, and England that owned both incunabula and manuscripts (1960, 62-65). He gives the specific examples of Corvinus's copies of Curtius Rufus printed by Vindelinus de Spira in 1471 and of St Jerome printed by Sweynheym and Pannartz in $1470(1960,62)$.

${ }^{26}$ Albert Derolez describes the general characteristics of the decoration and illustration in Marcatellis's books in 1979, 16-19.

${ }^{27}$ Derolez describes MS Mellon 25 in 1987, 480-488. It contains the series of astrological texts printed by Bonetus Locatellus (1493; ISTC ip01089000) and Johann Engles's Astrolabium planum in tabulis printed by Erhard Ratdolt (1488; ISTC ia00711000). The manuscript has been digitised and is available via the Beinecke Rare Book and Manuscript Library's Digital Collections:

https://beinecke.library.yale.edu. For a fuller discussion of this and other manuscripts copied from print at the Beinecke, see Nafde. "Manuscripts Copied from Printed Books now in the Beinecke Library”. Poetica 91 \& 92 (2019): 105-117. 
${ }^{28}$ This manuscript is described briefly by Derolez 1979, 154-161 and 1986, 152. This manuscript has been digitised and is available via Ghent University Library's Image Library: https://lib.ugent.be.

${ }^{29}$ It may be that the scribe was new to copying for Marcatellis's library as his hand differs from the script usual to Marcatellis's books; however this is not the case for the scribe of MS Mellon 25.

${ }^{30}$ Derolez gives a few examples 1986, 142-143.

${ }^{31}$ The 1505 date is recorded at the end of the text (fol. 336r). This manuscript is discussed briefly by Derolez 1979, 206-210 and 1986, 152-53. This manuscript has been digitised and is available via Ghent University Library’s Image Library: https://lib.ugent.be.

${ }^{32}$ There is a monogram, his name, and "mercer of London" on a flyleaf. See Bone.

${ }^{33}$ The manuscript is bound with three Caxton prints: Troilus and Criseyde ([1483]; STC 5094), The Canterbury Tales ([1483]; STC 5083) and Quattor Sermones ([1482-3]; STC 17957).

${ }^{34}$ As well as a book collector, Thorney was also Wynkyn de Worde's patron and he seems to have lent St John's 266 to de Worde for his edition of Siege of Thebes ([1494]; STC 17031). There are compositor's marks throughout the manuscript and a number of readings that are shared between the two (Bone, 294). The fact that the printed text was modelled on St John's MS 266, which itself was made to look like a printed text, neatly demonstrates the overlap between book forms and their aesthetics during this period of book production.

${ }^{35}$ It is unclear whether the first text in the manuscript is copied from print.

${ }^{36}$ The scribe of MS Mun.A.4.104 identifies himself as William Cotson in a series of colophons. The manuscript is digitised and available via Chetham's Library Digital Resources:

https://library.chethams.com/collections/digital-resources/

${ }^{37}$ The March 1490 date is the terminus ante quem for the manuscript, found in the colophon at the end of The Second Nun's Tale (fol. 173r); the other colophons in the manuscript have earlier dates.

${ }^{38}$ The quire number is sometimes written out in words rather than numbers, e.g. "Quaterno primo". "Folio" is sometimes abbreviated to "fol".

${ }^{39}$ Of course, as Woudhuysen argues, by the mid-sixteenth century, the value of the manuscript had changed in terms of its "social status, its personal appeal, relative privacy, freedom from government control, its cheapness, and its ability to make words quickly available to a select audience” (15). 